\title{
Anxiety and depression in mothers of newborns in intensive care units
}

How to cite this article:

Souza LG, Queiroz VC, Andrade SSC, César ESR, Melo VFC, Oliveira SHS. Anxiety and depression in mothers of newborns in intensive care units. Rev Gaúcha Enferm. 2021:42:e20200388. doi: https://doi. org/10.1590/1983-1447.2021.20200388 a Hospital Universitário Nova Esperança (HUNE). João Pessoa, Parába, Brasil.

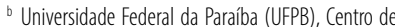
Ciências da Saúde, Programa de Pós-graduação em Enfermagem. João Pessoa, Paraíba, Brasil.

Faculdade de Enfermagem Nova Esperança (FACENE). João Pessoa, Parába, Brasil.

Universidade Federal da Parába (UFPB), Centro de Ciências da Saúde. João Pessoa, Paraíba, Brasil.
Larissa Gouveia de Souza ${ }^{a}$

Viviane Cordeiro de Queiroz ${ }^{b}$

Smalyanna Sgren da Costa Andrade Edna Samara Ribeiro Césarc Vilma Felipe Costa de Meloc Simone Helena dos Santos Oliveira ${ }^{d}$

\section{ABSTRACT}

Objective: To evaluate the classification and factors associated with anxiety and/or depression in mothers of newborns in a neonatal intensive care unit and elaborate the nursing process after psychological testing.

Method: A study conducted with 91 mothers of newborns in intensive care of northeastern maternity, through a Beck anxiety and depression characterization and inventory form.

Results: Majority with severe anxiety (93.4\%) and moderate depression (50.5\%). There was statistical significance between anxiety with planned pregnancy $(p=0.022)$ and vaginal delivery route $(p=0.028)$, as well as depression with abortion $(p=0.027)$ and mechanical ventilation $(p=0.017)$.

Conclusion: Route of delivery, unpaid occupation, income, kangaroo method adhering, supplementation, schooling, planned pregnancy, gestational age of birth and newborn weight impact emotional instability. Social support stands out as a protective factor for symptoms of anxiety and depression.

Keywords: Anxiety. Depression. Pregnant women. Nursing care. Intensive care units, neonatal.

\section{RESUMO}

Objetivo: Avaliar a classificação e fatores associados à ansiedade e/ou depressão em mães de recém-nascidos internos em unidade de terapia intensiva neonatal e elaborar o processo de enfermagem após teste psicológico.

Método: Pesquisa realizada com 91 mães de recém-nascidos internos em terapia intensiva de maternidade nordestina, por meio de formulário de caracterização e inventário de ansiedade e depressão de Beck.

Resultados: Maioria com ansiedade grave (93,4\%) e depressão moderada (50,5\%). Houve significância estatística entre ansiedade com gravidez planejada $(p=0,022)$ e via de parto vaginal $(p=0,028)$, bem como depressão com abortamento $(p=0,027)$ e ventilação mecânica $(p=0,017)$.

Conclusão: Via de parto, ocupação não remunerada, renda, adesão ao método canguru, suplementação, escolaridade, gravidez planejada, idade gestacional do nascimento e peso do neonato impactam na instabilidade emocional. 0 apoio social destaca-se como fator de proteção para sintomas de ansiedade e depressão.

Palavras-chave: Ansiedade. Depressão. Gestantes. Cuidados de enfermagem. Unidade de terapia intensiva neonatal.

\section{RESUMEN}

Objetivo: Evaluar la clasificación y los factores asociados a la ansiedad y/o depresión en madres de recién nacidos en una unidad de cuidados intensivos neonatales y elaborar el proceso de enfermería después de las pruebas psicológicas.

Método: Se realizó un estudio con 91 madres de recién nacidos en cuidados intensivos de maternidad nororiental, a través de un formulario de caracterización y un inventario de ansiedad y depresión de Beck.

Resultados: La mayoría con ansiedad severa $(93,4 \%)$ y depresión moderada (50,5\%). Hubo significación estadística entre la ansiedad con embarazo planificado ( $p=0,022)$ y la vía de parto vaginal $(p=0,028)$, así como la depresión con aborto $(p=0,027)$ y la ventilación mecánica $(p=0,017)$.

Conclusión: La vía de parto, la ocupación no remunerada, los ingresos, la adhesión al método canguro, la suplementación, la escolarización, el embarazo planificado, la edad gestacional del nacimiento y el peso del recién nacido afectan la inestabilidad emocional. El apoyo social se destaca como factor protector de los síntomas de ansiedad y depresión.

Palabras clave: Ansiedad. Depresión. Mujeres embarazadas. Atensión de enfermería. Unidad de cuidado intensivo neonatal. 


\section{口INTRODUCTION}

Anxiety and depression are emotional problems that intersect and each has its peculiarity. Anxiety is seen as a normal reaction of the body to a danger zone, becoming a disorder according to its intensity and frequency, which can affect work, well-being and personal relationships. In the case of depression, the enduring feeling is accompanied by the constant presence of negative thoughts, guilt, fear and decreased pleasure for daily activity, requiring psychological and psychiatric help ${ }^{(1)}$.

Biological and environmental factors can trigger anxiety and/or depression in the puerpery. In this context, the Neonatal Intensive Care Unit, as an area of care for vulnerable newborns who need specific and continuous care, can be an element that triggers emotional distress ${ }^{(2)}$.

Nevertheless, the hospital stay allows the newborn greater exposure to the procedures necessary for survival, which may decrease contact with the mother who may encounter psychic suffering in the face of the possibility of infant morbidity and mortality. For this, $46 \%$ of infant deaths occur in the first 28 days of life. Prospective trends show that 60 million children under five years of age will die between 2017 and 2030, half of them newborn ${ }^{(3)}$. In 2016 in Brazil, according to the second most updated report, the neonatal mortality rate was 14 per 1,000 live births (14/1,000 LB) $)^{(4)}$. In Paraíba, in that same year, the neonatal mortality rate was 8.47 per 1,000 live births $(8.47 / 1,000 \mathrm{LB})^{(5)}$.

In order to ensure health coverage and increased survival of newborns, health services need to offer adequate strategies for satisfactory care of children and their families after delivery ${ }^{(6)}$. From this perspective, the separation of the mother-child caused by the hospitalization of the child in a neonatal intensive care unit is one of the greatest difficulties of health services, because this experience can be traumatic of the mother and exert negative influence on the interactive mother-child behavior, triggering emotional problems, such as anxiety and depression in mothers and cognitive delays in the newborn ${ }^{(1)}$.

In this perspective, the Systematization of Nursing Care (SNC) is a care tool provided within health services, in an individualized, humanized and responsible way, which allows identifying and intervening in emotional problems, such as anxiety and depression in mothers of newborns hospitalized in an intensive care unit ${ }^{(7)}$.

Thus, considering the panorama of anxiety, depression and neonatal hospitalizations at the national and global level, the importance of the intensive care unit to increase the survival of newborns, the impact brought to the mothers of internal children, and finally, indicating nursing care as a relevant element to the care of individuals in various sectors, this research has the following fundamental questions: Do mothers of newborns have anxiety and/or depression resulting from the process of hospitalization of their children in an intensive care unit? What are the nursing diagnoses and possible interventions aimed at mothers after applying psychological tests? The aim of this study was to evaluate the classification and factors associated with anxiety and/ or depression in mothers of newborns in a neonatal intensive care unit and to elaborate the nursing process after psychological testing.

\section{METHOD}

Descriptive cross-sectional study and quantitative approach carried out in the neonatal intensive care sector of the Instituto Cândida Vargas (ICV), a reference maternity care in the care of pregnant women, puerperal women and high-risk newborns and the Hospital Amigo da Criança no Estado (IHAC) Initiative, located in the city of João Pessoa, Paraíba, Brazil.

The target population was composed of 91 mothers according to the following inclusion criteria: mothers with newborns hospitalized in intensive care units during the period in which the research took place, with age of majority, regardless of parity and schooling. The sample was calculated by means of simple random sampling (SRS) for finite sample, with an annual population of 230 mothers with their children interned in the intensive care unit in this maternity unit ${ }^{(8)}$. The confidence level was $95 \%$, with a margin of error of $5 \%$, i.e., $a=0.05(z=1.96), p=0.08$ and predicted losses of 0.2 . The probabilistic sample was calculated in 91 mothers of the ICV.

For the purpose of elucidating the calculation, $p$ is the proportion of the study's outcome variable. For unknown proportions, the value of $50 \%$ is admitted, i.e., 0.5 . A margin of error between $5 \%$ and $10 \%$ is usually used. Over the $z$, it means the percentile that reflects the degree of reliability over the maximum error. For the health area, $a=0.05$. This results in $z=1.96$. The proportion ( $p$ ) for the sample calculation in this study considered the average estimate of hospitalizations equivalent to $8.26 \%(0.08)$. The expected losses are equivalent to those that would give up after data collection, which is important for reliable maintenance of the sample.

The form was composed of sociodemographic data, life habits, sexual, reproductive characteristics and questions related to the newborn, in addition to Beck's Depression Inventory (BDI) and Anxiety Inventory (Al), which are instruments with the use of scales (BAI). Beck's BDI contains 21 multiple choice items, the intensity of which ranges from 0 to 3 , referred to sadness, pessimism, feeling of punishment, 
self-accusation, thought of suicide, crying crises, irritability, social retraction, low income for work, indecision, body image distortion, sleep disorder, fatigue, appetite loss, weight loss, somatic concern, restriction of libido. The classification has the following cutoff points: $\leq 10$ (without depression or minimal depression), 10-18 (mild to moderate depression), 18-29 (moderate to severe depression), 30-63 (severe depression). It recommends a score above 15 to identify dysphoria and conclude that the term "depression" should be used for subjects with a score above 20 with diagnosis ${ }^{(9)}$.

The anxiety inventory (BAI) consists of 21 items, which should be evaluated by the individuals themselves on a fourpoint scale, namely: 0 (absolutely not), 1 (slightly anxious), 2 (moderately anxious), 3 (severely anxious). The duration of application is about five to ten minutes. Being classified the following cutoff points, 0-10 (minimum symptoms), 11-19 (mild symptoms), 20-30 (moderate symptoms), 31-63 (severe symptoms) $)^{(9)}$.

The research took place in the morning and sunday shifts during march and April 2020. In this study, we opted for an individual interview for participants with any level of education, so the instrument was adapted to a form. After prior authorization from the ICV responsible sector and assent of the Ethics and Research Committee, data were collected by a nurse at the hospital on daily duty. The interview was conducted in a suitable and comfortable room, ensuring the confidentiality and confidentiality of the mothers, according to the days and times pre-established. The collection occurred with each mother at a single moment.

Data analysis was performed with the help of the IBM Statistics Package for the Social Sciences (SPSS), version 21. The results were presented in tables containing absolute, relative frequency and the picture with the nursing process. The data were associated with the Chi-Square test when the expected frequency was greater than five in the cells and the Fisher's Exact Test, when the expected frequency was less than five, with statistical significance for $\leq 0.05$ results.

To verify probability of the phenomenon, the Odds Ratio, i.e., Odds Ratio (OR). The ratio of chance and confidence interval indicates the chance or protection determined by the variables (significant values do not permeate the nullity symbolized by the number 1). When the value is greater than 1 , the reading presents with the amount of times of this value occurs with a chance of outcome. In case the value is less than 1 , there are two forms of reading for this protection factor, namely: a) the value revealed as a percentage for the highest chance of not presenting (non-occurrence of the outcome); b) the revealed value subtracted from number 1 , indicating a lower chance in the percentage of occurrence of the outcome. In this study, the second statement for reading was used for the protection factor.

For the construction of the Nursing Process, Nursing Diagnoses (ND) were formulated from BAI and BDI, whose symptoms emerged as defining characteristics. To select the clinical manifestations of the instruments, it was established that symptoms whose women referred to the "zero" point would be excluded, that is, absolutely not.

Therefore, as the nursing process in this sample was elaborated collectively, if at least one respondent cited absence of that symptom, it would no longer be a defining characteristic, because it would not apply to all. The Nursing Diagnoses were elaborated with the help of the Portuguese version of the International Classification for Nursing Practice - ICNP®(10), using the elements of focus and judgment, and were ascertained as to their description to maintain the coherence of the symptom explained in BAI and BDI. The planning and interventions were elaborated according to the logical reasoning in relation to the symptoms (defining characteristics) evidenced.

The present study respected the ethical aspects related to research with human beings, as well as the signing of the Free and Informed Consent Form. The project was approved under protocol n. 208/2020, according to CAAE n.28313620.4.0000.5179.

\section{DESULTS}

The mean age of the mothers was 23.33 years $(S D \pm 4,240)$. Regarding the age group, there were 64 (70\%) women between $18-25$ years and $27(28 \%) \geq 26$ years old. On schooling, 10 (11\%) had elementary school I, 33 (36\%) fundamental II, 45 (49\%) high school and 3 (3\%) being higher education. About occupation, 19 (21\%) were students, 27 (30\%) autonomous and 31 (34\%) unemployed.

Regarding naturalness, 69 (76\%) reside in the city of research and 22 (24\%) in other cities. About religion, 45 (49\%) were Catholic, 28 (31\%) evangelicals and 18 (20\%) had other religions not explained. As for ethnicity, 36 (38\%) were white, 9 (10\%) black, 23 (25\%) browns and 11 (12\%) Asian. Finally, monthly income, 85 (93\%) with a minimum wage, 6 (6\%) with more than one minimum wage.

On sexual, reproductive and obstetric characteristics, the mean sexarche age was 15.18 years (SD \pm 1.841 ), with 19 (21\%) women with sexarche up to 13 years and $72(79 \%) \geq$ 14 years old. In marital status, 60 (66\%) lived with partners and 31 (35\%) without partner. As for contraceptive methods, 57 (63\%) condoms, 27 (28\%) took the pill and 3 (3\%) used the injectable hormonal contraceptive. 
Regarding parity, 36 (39\%) were primiparous and 55 (60\%) multigestas, 79 (86\%) never aborted and $12(13 \%)$ have been aborted. The type of delivery elicited by 48 (52\%) mothers was caesarean section surgery and 43 (47\%) were vaginal. About children, 36 (39\%) had only one child, 55 (60\%) more than two children. Regarding prenatal care visits, 55 (60\%) conducted 1 to 5 consultations and 36 (39\%) held more than six consultations.

Regarding life habits, of the 91 mothers participating in the study, 75 (82.4\%) were not smokers, and 52 (57.1\%) non-etilist. Regarding leisure, 70 (76.9\%) recreational activities once a month and 21 (23.1\%) two or three times a month.

Regarding the average weight of the newborn, the mean was 2,692g (SD \pm 349.9 ), with 27 (29\%) less than 2,500g and 64 (70\%) greater than 2,500g. About gestational weeks, 28 (30\%) were 36 weeks and 63 (69\%) more than 37 weeks. Regarding the practice of the kangaroo method, 69 (75\%) used and 22 (24\%) not. About newborns in supplementation, 57 (62\%) supplementation and 34 (37\%) not used. Regarding the bed bank, 65 (71\%) made use of the stock and 26 (28\%) No. Mechanical ventilation was required for $33(36 \%)$ and $58(63 \%)$ not used.

The mean sum of the classifications for anxiety was 35.91 ( $S D \pm 4.518$ ) and depression was 30.00 ( $S D \pm 3.269$ ). Regarding the classifications, all women fit into some degree of mental illness. On the prevalence of anxiety symptoms, 85 (93\%) were severe and six (6\%) had moderate symptoms. As for depression, 46 (50\%) had moderate symptoms and 45 (49\%) had severe symptoms.

According to Table 1, the association between sociodemographic, obstetric and life habits with anxiety, through fisher's exact test, presented statistical significance, with planned pregnancy $(p=0.022)$ and vaginal delivery $(p=0.028)$. Mothers with cesarean section have $12 \%(\mathrm{OR}=0.875[\mathrm{Cl}=0.786-0.974)]$ less likely to have severe anxiety compared to women with vaginal delivery. Women with planned pregnancy are 10\% more likely to have severe anxiety (OR=10.179 [Cl=1.134-91,327]).

Women with unpaid occupation $(\mathrm{OR}=0.893[\mathrm{Cl}=0.815$ $0.978]$ ), higher income (0.929 [0.877-0.985], not adept at the kangaroo method $(\mathrm{OR}=0.913[\mathrm{Cl}=0.849-0.982])$ and that their babies did not use supplementation ( $\mathrm{OR}=0.895 \mathrm{Cl}=0.819$ 0.978 ]) had 10\%,7\%,8\% and $10 \%$ less chance of having severe anxiety, constituting protective factors. In addition, women with higher schooling $(\mathrm{OR}=1.080[\mathrm{Cl}=1.015-1.149])$, those who had their babies at $\geq 37$ weeks of gestation ( $O R=1.105$ $[\mathrm{Cl}=1.020-1,197])$, whose babies had birth weight $>2,500 \mathrm{~g}$ $(\mathrm{OR}=1.103$ [1.020-1.1194]) are more likely to have severe anxiety (Table 1).

There was statistical significance between the presence of depressive symptoms with abortion $(p=0.027)$ and mechanical ventilation ( $p=0.017$ ). It is noteworthy that the kangaroo method was close to significance ( $p=0.053$ ). Women with children who used mechanical ventilation had $67.1 \%$ ( $\mathrm{OR}=0.329[\mathrm{Cl}=1.009-7.691])$ less likely to have moderate depression compared to mothers whose children are not being ventilated (Table 2).

This investigation showed that women without abortion were 5.97 times more likely $(\mathrm{OR}=5.972[\mathrm{Cl}=1.228-29,036])$ to present symptoms of severe depression, as well as mothers adept to the kangaroo method were 2.78 times more likely ( $\mathrm{OR}=2.786[\mathrm{Cl}=1.009-7.691])$ to present depressive symptoms at both levels. Absence of a partner was a protective factor for severe depression, in which women without a partner had $66 \%(\mathrm{OR}=0.340[\mathrm{Cl}=0.137-0.846])$ less likely to have this outcome in relation to those with partnership (Table 2).On the manifestations common to all participants, according to BAI and $B D I$, table 3 shows the degrees of symptoms. It should be noted that the sum of the percentages should be carried out per line, because each manifestation was distributed according to the classification of anxiety and depression.

Chart 1 observes the nursing processes applied to these mothers according to each manifestation presented in the instrument used. 
Table 1 - Odds ratio and association between anxiety with sociodemographic, obstetric variables and life habits. João Pessoa, Paraíba, Brazil, 2020. $(n=91)$

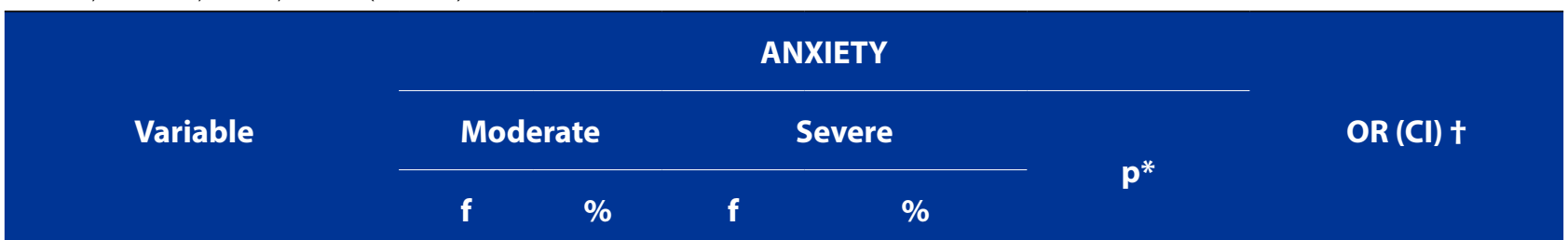

\section{Occupation}

$\begin{array}{lcccccc}\text { Paid } & 6 & 6.6 & 50 & 54.9 & 0.780 & 0.893 \\ \text { Not Paid } & 0 & - & 35 & 38.5 & & (0.815-0.978)\end{array}$

\section{Religion}

$\begin{array}{llllccc}\text { Catholic } & 3 & 3.3 & 42 & 46.2 & 1.000 & 1.024 \\ \text { Non-Catholic } & 3 & 3.3 & 43 & 47.2 & & (0.195-5.362)\end{array}$

\section{Education}

$\begin{array}{llllccc}\text { Up to Primary School } & 0 & - & 10 & 11 & 1.000 & 1.080 \\ \text { From High School } & 6 & 6.6 & 75 & 82.4 & & (1.015-1.149)\end{array}$

\section{Age Group}

$\begin{array}{lllllcc}18-25 \text { years } & 2 & 2.2 & 62 & 68.1 & 0.061 & 0.185 \\ \geq 26 \text { years } & 4 & 4.4 & 23 & 25.3 & & (0.032-1.082)\end{array}$

\section{Color}

$\begin{array}{lcccccc}\text { White } & 4 & 4.4 & 32 & 35.2 & 0.209 & 3.313 \\ \text { Not White } & 2 & 2.2 & 53 & 58.2 & & (0.547-19.123)\end{array}$

\section{Income*}

$\begin{array}{lcccccc}\text { Up to } 1 \mathrm{MW} & 6 & 6.6 & 79 & 86.8 & 1.000 & 0.929 \\ \text { Over } 2 \mathrm{MW} & 0 & - & 6 & 6.6 & & (0.877-0.985)\end{array}$

\section{Smoker}

\begin{tabular}{lllllll} 
Yes & 1 & 1.1 & 15 & 16.5 & 1.000 & 0.933 \\
No & 5 & 5.5 & 70 & 76.9 & & $(0.102-8.579)$ \\
\hline
\end{tabular}


Table 1 - Cont.

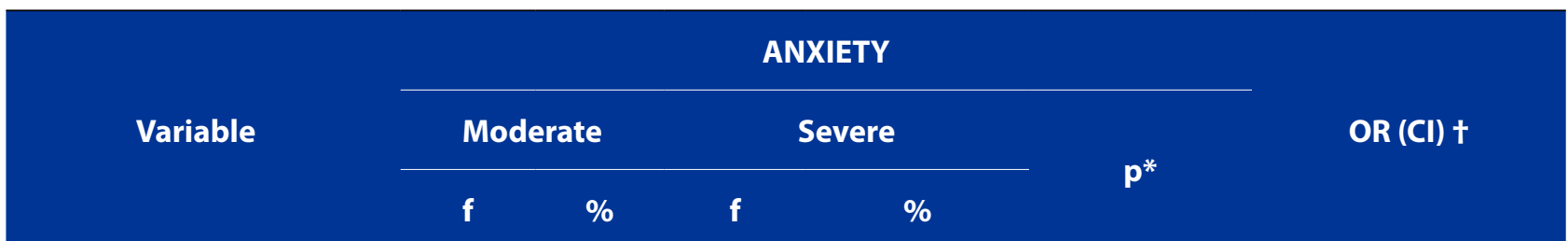

\section{Acohol Consumer}

$\begin{array}{lllllll}\text { Yes } & 2 & 2.2 & 37 & 40.7 & 0.697 & 0.649 \\ \text { No } & 4 & 4.4 & 48 & 52.7 & (0.113-3.735)\end{array}$

\section{Leasure}

0-1 time in a month

$5 \quad 5.5 \quad 65$

71.4

1.000

1.538

2-3 times in a month

$1.1 \quad 20$

22

$(0.170-13.951)$

\section{Marital Status}

With partner

Without partner

$5 \quad 5.5 \quad 55$

60.4

0.429

33

(0.304-24.433)

\section{Planned Pregnancy}

$\begin{array}{lllllll}\text { No } & 5 & 5.5 & 28 & 30.8 & 0.022 \neq & 10.179 \\ \text { Yes } & 1 & 1.1 & 57 & 62.6 & & (1.134-91.327)\end{array}$

\section{Parity}

Primiparous

Multiparous

\section{Abortion}

Yes

No

\section{Delivery Route}

Cesarean Section

Vaginal

\section{Number of children}

$\begin{array}{lllllll}\text { Only } 1 & 1 & 1.1 & 35 & 38.5 & 0.397 & 0.286 \\ \geq 2 & 5 & 5.5 & 50 & 54.9 & (0.032-2.553)\end{array}$


Table 1 - Cont.

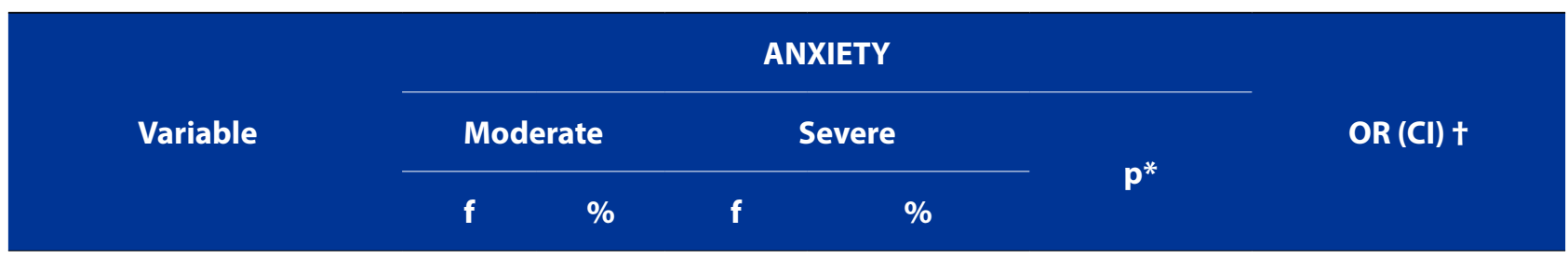

\section{Prenatal consultations}

$\begin{array}{lllllll}1-5 \text { consultations } & 2 & 2.2 & 53 & 58.2 & 0.209 & 0.302 \\ \geq 6 \text { consultations } & 4 & 4.4 & 32 & 35.2 & & (0.052-1.743)\end{array}$

\section{Baby's weight}

$\begin{array}{lllllll}<2.500 \mathrm{~g} & 0 & - & 27 & 29.7 & 0.174 & 1.103 \\ >2.500 \mathrm{~g} & 6 & 6.6 & 58 & 63.7 & (1.020-1.194)\end{array}$

\section{Kangaroo Method}

$\begin{array}{llllllll}\text { Yes } & 6 & 6.6 & 63 & 69.2 & 0.329 & 0.913 \\ \text { No } & 0 & - & 22 & 24.2 & & (0.849-0.982)\end{array}$

\section{Supplementation}

Yes

No

\section{Milk Bank}

Yes

No

\section{Mechanical ventilation}

$\begin{array}{llllccrr}\text { Yes } & 1 & 1.1 & 32 & 35.2 & 0.411 & 0.331 & \\ \text { No } & 5 & 5.5 & 53 & 58.2 & (0.037-2.964)\end{array}$

Gestational age

\begin{tabular}{lllllll}
$\leq 36$ weeks & 0 & - & 28 & 30.8 & 0.172 & 1.105 \\
$\geq 37$ weeks & 6 & 6.6 & 57 & 62.6 & $(1.020-1.197)$ \\
\hline
\end{tabular}

Source: Research data, 2020

*statistical significance; +OR: Odds Ratio/Cl: Confidence Interval; FFisher's Exact Test. 
Table 2 - Odds ratio and association between depression with sociodemographic, obstetric variables and life habits. João Pessoa, Paraíba, Brazil, 2020. ( $\mathrm{n}=91)$

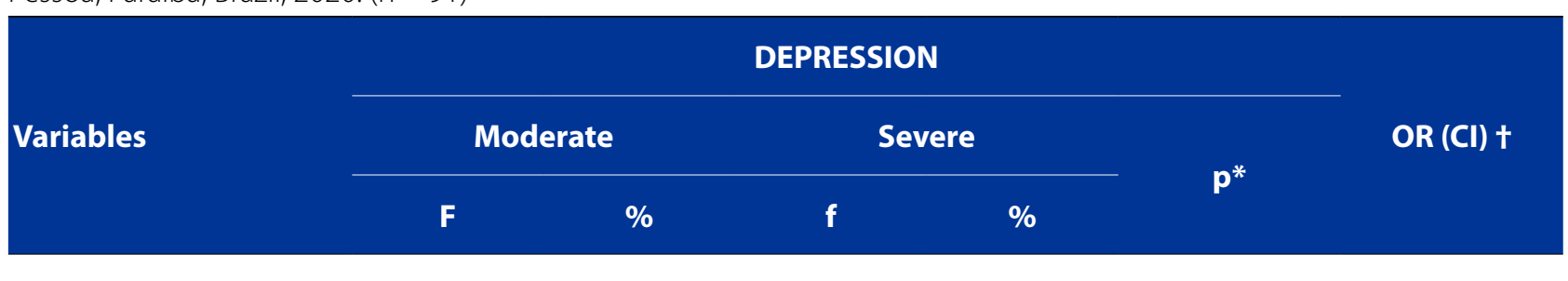

\section{Occupation}

$\begin{array}{lcccccc}\text { Paid } & 31 & 34 & 25 & 27.5 & 0.246 & 1.653 \\ \text { Not Paid } & 15 & 16.5 & 20 & 22 & (0.705-3.876)\end{array}$

\section{Religion}

$\begin{array}{lcccccc}\text { Catholic } & 26 & 28.6 & 19 & 20.9 & 0.173 & 1.779 \\ \text { Non-Catholic } & 20 & 22 & 26 & 28.5 & & (0.775-4.082)\end{array}$

\section{Education}

$\begin{array}{lrrrrrr}\text { Up to Primary School } & 5 & 5.5 & 5 & 5.5 & 1.000 & 0.976 \\ \text { From High School } & 41 & 45.1 & 40 & 44.1 & & (0.262-3.630)\end{array}$

\section{Age Group}

$\begin{array}{lllllll}18-25 \text { years } & 33 & 36.3 & 31 & 34.1 & 0.821 & 1.146 \\ \geq 26 \text { years } & 13 & 14.3 & 14 & 15.3 & & (0.466-2.820)\end{array}$

\section{Color}

$\begin{array}{lcccccc}\text { White } & 50 & 54.9 & 10 & 12.1 & 0.749 & 1.163 \\ \text { Not White } & 23 & 25.3 & 7 & 7.7 & & (0.460-2.939)\end{array}$

\section{Income*}

$\begin{array}{lcccccc}\text { Up to } 1 \mathrm{MW} & 41 & 45.1 & 44 & 48.4 & 0.203 & 0.186 \\ \text { Over } 2 \mathrm{MW} & 5 & 5.5 & 1 & 1 & & (0.021-1.663)\end{array}$

\section{Smoker}

\begin{tabular}{ccccccc} 
Yes & 9 & 9.9 & 7 & 7.6 & 0.784 & 1.320 \\
No & 37 & 40.7 & 38 & 41.8 & & $(0.446-3.914)$ \\
\hline
\end{tabular}


Table 2 - Cont.

\begin{tabular}{|c|c|c|c|c|c|c|}
\hline \multirow{3}{*}{ Variables } & \multicolumn{5}{|c|}{ DEPRESSION } & \multirow{3}{*}{ OR (CI) † } \\
\hline & \multicolumn{2}{|c|}{ Moderate } & \multicolumn{2}{|c|}{ Severe } & \multirow{2}{*}{$p^{*}$} & \\
\hline & $\mathbf{F}$ & $\%$ & f & $\%$ & & \\
\hline \multicolumn{7}{|c|}{ Acohol Consumer } \\
\hline Yes & 19 & 20.8 & 20 & 22 & 0.834 & 0.880 \\
\hline No & 27 & 29.7 & 25 & 27.5 & & $(0.383-2.019)$ \\
\hline
\end{tabular}

\section{Leasure}

0-1 time in a month

2-3 times in a month

\section{Marital Status}

With partner

Without partner

\section{Planned Pregnancy}

No

Yes

\section{Parity}

Primiparous

Multiparous

\section{Abortion}

Yes

No

\section{Delivery Route}

Cesarean Section

Vaginal

\section{Number of children}

26

20

38

8

25

21

14

32

15

31

10

36

28.6

22

17.6

33

23.1
35.2

0.221

14.2

13

35

38.4

0.383

0.340

10

11

(0.137-0.846)

(0.711-5.237)

1.930

$\begin{array}{lllllll}\text { Only } 1 & 16 & 17.6 & 20 & 22 & 0.395 & 0.667 \\ \geq 2 & 30 & 33 & 25 & 27.4 & (0.286-1.522)\end{array}$


Table 2 - Cont.

\begin{tabular}{|c|c|c|c|c|c|}
\hline \multirow{3}{*}{ Variables } & \multicolumn{4}{|c|}{ DEPRESSION } & \multirow{3}{*}{ OR $(\mathrm{CI}) \dagger$} \\
\hline & Moderate & & & & \\
\hline & $\%$ & f & $\%$ & & \\
\hline
\end{tabular}

\section{Prenatal consultations}

$\begin{array}{lcccccc}1-5 \text { consultations } & 28 & 30.8 & 27 & 29.6 & 1.000 & 1.037 \\ \geq 6 \text { consultations } & 18 & 19.8 & 18 & 19.8 & (0.448-2.403)\end{array}$

\section{Baby's weight}

$\begin{array}{lllllll}<2.500 \mathrm{~g} & 14 & 15.4 & 13 & 14.3 & 1.000 & 1.077 \\ >2.500 \mathrm{~g} & 32 & 35.2 & 32 & 35.1 & (0.375-2.685)\end{array}$

\section{Kangaroo Method}

$\begin{array}{ccccccc}\text { Yes } & 39 & 42.9 & 30 & 33 & 0.053 \neq & 2.786 \\ \text { No } & 7 & 7.7 & 15 & 16.4 & & (1.009-7.691)\end{array}$

\section{Supplementation}

$\begin{array}{lllllll}\text { Yes } & 28 & 30.8 & 29 & 31.9 & 0.829 & 0.858 \\ \text { No } & 18 & 19.7 & 16 & 17.6 & (0.367-2.009)\end{array}$

\section{Milk Bank}

$\begin{array}{lllllll}\text { Yes } & 29 & 31.9 & 36 & 39.6 & 0.104 & 0.426 \\ \text { No } & 17 & 18.8 & 9 & 9.9 & (0.166-1.097)\end{array}$

\section{Mechanical ventilation}

$\begin{array}{lllllll}\text { Yes } & 11 & 12.1 & 22 & 24.2 & 0.017 \neq & 0.329 \\ \text { No } & 35 & 38.4 & 23 & 25.3 & (0.134-0.804)\end{array}$

\section{Gestational age}

\begin{tabular}{lllllrr}
$\leq 36$ weeks & 14 & 15.4 & 14 & 15.4 & 1.000 & 0.969 \\
$\geq 37$ weeks & 32 & 35.2 & 31 & 34 & $(0.398-2.360)$ \\
\hline
\end{tabular}

Source: Research data, 2020

*statistical significance; TOR: Odds Ratio/Cl: Confidence Interval; ;Fisher's Exact Test. 
Table 3 - Distribution of symptom degrees according to the items defined for the elaboration of the nursing process applied to mothers of internal newborns in intensive care unit. João Pessoa, Paraíba, Brazil, 2020. ( $n=91)$

\begin{tabular}{lccc}
\multicolumn{1}{c}{ Manifestations of Beck Anxiety Inventory } & \\
\hline \multicolumn{1}{c}{ Variables } & Mild & Moderate & Severe \\
\hline Tremors in the legs & $14(15.3 \%)$ & $37(40.7 \%)$ & $40(44.0 \%)$ \\
Unable to relax & $40(44.0 \%)$ & $30(33.0 \%)$ & $21(23.0 \%)$ \\
Heart palpitation & $45(49.5 \%)$ & $36(39.5 \%)$ & $10(11.0 \%)$ \\
or acceleration & $49(53.8 \%)$ & $30(33.0 \%)$ & $12(13.2 \%)$ \\
Difficulty to breath & $18(19.8 \%)$ & $46(50.5 \%)$ & $27(29.7 \%)$ \\
Scared & Manifestations of Beck Anxiety lnventory & Severe \\
\hline \multicolumn{1}{c}{ Variables } & Mild & Moderate & $7(7.7 \%)$ \\
\hline Sadness & $49(53.8 \%)$ & $35(38.5 \%)$ & $29(31.9 \%)$ \\
Discouragement & - & $62(68.1 \%)$ & $14(15.4 \%)$ \\
Failure & $44(48.4 \%)$ & $33(36.2 \%)$ & $22(24.1 \%)$ \\
Dissatisfaction & $36(39.6 \%)$ & $33(36.3 \%)$ & $9(9.9 \%)$ \\
Appetite & $45(49.4 \%)$ & $37(40.7 \%)$ & \\
\hline So & & & \\
\hline
\end{tabular}

Source: Research data, 2020.

\begin{tabular}{|c|c|c|c|c|}
\hline \multirow{2}{*}{\begin{tabular}{c|}
$\begin{array}{c}\text { Defining } \\
\text { Characteristic }\end{array}$ \\
Manifestations
\end{tabular}} & \multicolumn{2}{|c|}{ Nursing Diagnosis } & \multirow{2}{*}{ Planning } & \multirow{2}{*}{ Intervention } \\
\hline & Focus & Judgement & & \\
\hline $\begin{array}{l}\text { Tremors in } \\
\text { the legs }\end{array}$ & $\begin{array}{l}\text { Risk for body } \\
\text { movement }\end{array}$ & Increased & $\begin{array}{l}\text { Reduced } \\
\text { negative } \\
\text { consequences } \\
\text { of tremors }\end{array}$ & $\begin{array}{l}{ }^{*} \text { Guide to the possibility of trauma. } \\
{ }^{*} \text { Assist in the care activities of the newborn. } \\
\text { * Instruct on risk reduction posture. } \\
\text { * Provide calm environment with } \\
\text { minimal stressors. }\end{array}$ \\
\hline $\begin{array}{l}\text { Unable } \\
\text { to relax }\end{array}$ & Sleep pattern & Altered & $\begin{array}{l}\text { Relaxation } \\
\text { Promotion }\end{array}$ & $\begin{array}{l}\text { * Demonstrate relaxation techniques } \\
\text { * Assist in creating a schedule of daily activities }\end{array}$ \\
\hline $\begin{array}{l}\text { Heart } \\
\text { palpitation } \\
\text { or acceleration }\end{array}$ & $\begin{array}{l}\text { Risk of blood } \\
\text { pressure }\end{array}$ & Altered & $\begin{array}{l}\text { Maintenance } \\
\text { of sensitive } \\
\text { pressure and } \\
\text { emotional state }\end{array}$ & $\begin{array}{l}\text { * Help the patient recognize signs of increased } \\
\text { or decreased blood pressure and anxiety. } \\
\text { * Support the mother by listening to her needs. } \\
\text { * Encourage to express her concerns. }\end{array}$ \\
\hline
\end{tabular}

Chart 1 - Nursing process applied to mothers of newborn inpatients in intensive care unit according to elicitly manifestations in Beck Anxiety and Depression Inventory. João Pessoa, Paraíba, Brazil, 2020 


\begin{tabular}{|c|c|c|c|c|}
\hline \multirow{2}{*}{\begin{tabular}{c|}
$\begin{array}{c}\text { Defining } \\
\text { Characteristic }\end{array}$ \\
Manifestations
\end{tabular}} & \multicolumn{2}{|c|}{ Nursing Diagnosis } & \multirow{2}{*}{ Planning } & \multirow{2}{*}{ Intervention } \\
\hline & Focus & Judgement & & \\
\hline $\begin{array}{l}\text { Difficulty } \\
\text { to breath }\end{array}$ & $\begin{array}{l}\text { Risk of } \\
\text { respiratory } \\
\text { pattern }\end{array}$ & Altered & $\begin{array}{l}\text { Improvement of } \\
\text { respiratory pattern }\end{array}$ & $\begin{array}{l}\text { * Guide on the technique for } \\
\text { breathing exercises. } \\
{ }^{*} \text { Monitor respiratory pattern. } \\
{ }^{*} \text { Check for signs of agitation. }\end{array}$ \\
\hline Scared & $\begin{array}{l}\text { Risk of } \\
\text { disorganized } \\
\text { behavior }\end{array}$ & Increased & Reduction of fear & $\begin{array}{l}\text { * Provide correct information using simple } \\
\text { terms. } \\
\text { * Encourage patients to verbalize any fear and } \\
\text { concern. } \\
\text { * Speak calmly and slowly * Provide tranquility } \\
\text { and comfort. } \\
\text { *Indicate psychotherapy. }\end{array}$ \\
\hline Sadness & $\begin{array}{l}\text { Risk for } \\
\text { Depression }\end{array}$ & Increased & $\begin{array}{l}\text { Reduction of } \\
\text { sadness }\end{array}$ & $\begin{array}{l}\text { * Stimulate dialogue } \\
\text { * Encourage family visit } \\
\text { * Provide distraction methods } \\
\text { * Guide engagement in support groups. }\end{array}$ \\
\hline Discouragement & $\begin{array}{l}\text { Risk of } \\
\text { hopelessness }\end{array}$ & Increased & $\begin{array}{l}\text { Improvement } \\
\text { of the mood }\end{array}$ & $\begin{array}{l}\text { * Help women prioritize activities. } \\
\text { * Identify and control factors that lead the } \\
\text { woman to discouragement. } \\
\text { * Keep the atmosphere receptive } \\
\text { and welcoming. }\end{array}$ \\
\hline Failure & $\begin{array}{l}\text { Risk } \\
\text { of frustration }\end{array}$ & Increased & $\begin{array}{l}\text { Improvement } \\
\text { of self-esteem }\end{array}$ & $\begin{array}{l}\text { * Identify negative self-critical discourses } \\
\text { * Score the evolution of the development of } \\
\text { the newborn. } \\
\text { * Praise the care and attention aimed at } \\
\text { the child } \\
\text { * Ask the woman to point out the best } \\
\text { achievements of her life. }\end{array}$ \\
\hline Dissatisfaction & $\begin{array}{l}\text { Risk of } \\
\text { negation } \\
\text { capacity to } \\
\text { manage life }\end{array}$ & Increased & $\begin{array}{l}\text { Increased level of } \\
\text { satisfaction for life }\end{array}$ & $\begin{array}{l}\text { * Stimulate positive thinking. } \\
\text { * Ensure psychological support by the } \\
\text { health team. } \\
\text { * Indicate support group of mothers of } \\
\text { newborn inpatients as a strategy to promote } \\
\text { acceptance of the situation. }\end{array}$ \\
\hline Appetite & Food intake & Decreased & $\begin{array}{l}\text { Improvement of } \\
\text { food pattern }\end{array}$ & $\begin{array}{l}\text { *Request nutritional guidance from the health } \\
\text { service team. } \\
\text { * Inform the patient about the importance } \\
\text { of food intake for the breastfeeding of } \\
\text { the newborn. }\end{array}$ \\
\hline
\end{tabular}

Chart 1 - Cont.

Source: Research data, 2020. 


\section{DISCUSSION}

The sociodemographic profile of the women in this study was not related to anxiety and depression, although important variables of risk and protection to emotional disorders were shown. A study conducted in a northeastern capital showed losses in the high mother-child relationship when associated with risk factors such as lower mother's schooling ${ }^{(11)}$, strengthening the impact of this sociodemographic variable on repercussions on the binomial.

Low schooling, primiparity, insecurity in care and absence of health insurance may favor postpartum depression among Asian women ${ }^{(12)}$. In Amsterdam, anxiety and depression presented risk factors associated with occupation in agriculture and livestock, history of unplanned pregnancy and tobacco use ${ }^{(13)}$.

In this investigation, marital status, abortion episode, kangaroo method adhering and mechanical ventilation aligned with emotional outcomes. It is noteworthy that there is evidence of an association between the hospitalization process and the mental health status of the family conducting anxiety ${ }^{(14)}$. In Florida, considerable prevalences of baby blues (puerperal dysphoria), followed by postpartum depression and anxiety disorder, indicate family support as an element of high impact to mental illness ${ }^{(15)}$.

Studies indicate a decrease in the depression score among mothers who were adept at the kangaroo method ${ }^{(1,6,16)}$, being associated with the effect of oxytocin release during physical contact of the method ${ }^{(17)}$. These results are discordant from the findings of this study and there are no qualitative explanations, although it is believed that this outcome is related to attachment, that is, mothers who perform the technique, may feel more powerless for the newborn's permanence in the hospital sector, generating a greater sense of sadness.

Prematurity did not statistically impact the result, but a North American investigation with 62 mothers of premature infants (gestational age $<37$ weeks) showed high levels of depression and anxiety, the latter being more prevalent in mothers of babies born before 32 gestational weeks, due to the marked amount of invasive procedures ${ }^{(18)}$.

Regarding the clinical manifestations related to anxiety and depression, the report of couples of premature babies pointed out that feelings such as anguish, impotence, fear and desire to escape are part of the daily life of the family that has a child hospitalized in the NICU, with a significant relationship between these feelings and personal and socioeconomic factors ${ }^{(19)}$.

Interventions focused on the mental health of mothers during the hospitalization of the child include interactions between the mothers of the group and execution of activities directed to the context (wheel of conversations and exchange of experiences experienced) ${ }^{(20)}$. In addition, the welcoming relationship, sensitive listening and care of the health team directed to mothers of babies in the NICU were strategies used to improve well-being in the face of the family's stay in the hospital ${ }^{(7)}$.

\section{CONCLUSION}

There was mental illness with severe anxiety and moderate depression in most mothers of newborns in patients in a neonatal intensive care unit. Variables such as fixed partnership, planned pregnancy, vaginal delivery route, abortion, mechanical ventilation, adoption of the kangaroo method and supplementation are related to risk or protection to the emotional disorders studied, demonstrating the need to elaborate the nursing process in order to increase the resolution of this problem in health services at this level of complexity.

The study in only one reference maternity of the State, with the seal of Hospital Amigo da Criança, as well as the non-execution and evaluation of the interventions elaborated, constitute limitations of the research. The contributions are anchored in the effectiveness of the use of multidisciplinary scales of psychological evaluation, provided that there is a research team integrated with other areas, as well as its intersection with the systematization of care, conferring autonomy in nursing care.

\section{REFERENCES}

1. Trumello C, Candelori C, Cofini M, Cimino S, Cerniglia L, Paciello, M, et al. Mothers' depression, anxiety, and mental representations after preterm birth: a study during the infant's hospitalization in a neonatal intensive care unit. Front Public Health. 2018;6:359. doi: https://doi.org/10.3389/fpubh.2018.00359

2. Salah M, Breaka R, Alkasseh A. Prevalence of anxiety and depression among mothers of newborns admitted to neonatal intensive care units in Gaza strip. EPOA. 2018;2(1):10-14. doi: https://doi.org/10.33805/2638-8073.109

3. United Nations Children's Fund (US). Levels e trends in child mortality. estimates developed by the UN inter-agency group for child mortality estimation. New York: UNICEF; 2017. [cited 2020 Jul 17]. Available from: https://crianca.mppr.mp.br/ arquivos/File/publi/unicef_relatorios/child_mortality_report_unicef_2017.pdf

4. Ministério da Saúde (BR). Secretaria de Vigilância em Saúde. Departamento de Análise em Saúde e Vigilância de Doenças não Transmissíveis. Saúde Brasil 2019 uma análise da situação de saúde com enfoque nas doenças imunopreveníveis e na imunização. Brasília: Ministério da Saúde; 2019 [cited 2021 Jul 17]. Available from: https://bvsms.saude.gov.br/bvs/publicacoes/saude_brasil_2019_analise_ situacao.pdf

5. Araújo RF, Costa KKD, Silva FMF, Diniz CR, Alves MM. Índice de mortalidade infantil no nordeste brasileiro entre 2015 e 2017. Rev Enferm Digit Cuid Promoção Saúde. 2020;5(1):19-23. doi: http://www.doi.org/10.5935/2446-5682.20200005 
6. Smith ER, Bergelson I, Constantian S, Valsangkar B, Chan GJ. Barriers and enablers of health system adoption of kangaroo mother care: a systematic review of caregiver perspectives. BMC Pediatr. 2017;17:35. doi: https://doi.org/10.1186/ s12887-016-0769-5

7. Almeida CR, Morais AC, Lima KDF, Cohim ACO. Daily routine of accompanying mothers in the neonatal intensive care unit. J Nurs UFPE on line. 2018 [cited 2020 0ct 21];12(7):1949-56. Available from: https://periodicos.ufpe.br/revistas/ revistaenfermagem/article/view/22640/29523

8. Consolidado das internações de recém-nascidos na unidade de terapia intensiva no ano de 2019. João Pessoa: Instituto Cândida Vargas; 2019.

9. Cunha JA. Manual da versão em português das Escalas Beck. São Paulo: Casa do Psicólogo; 2001.

10. International Council of Nurses (CH). CIPE versão 2017 - português do Brasil. 2017 [cited 2020 Mar 18]. Available from: https://www.icn.ch/sites/default/ files/inline-files/icnp-brazil-portuguese-translation-2017.pdf

11. Cavalcante MCV, Lamy Filho F, França AKTC, LamyZC. Relação mãe-filho e fatores associados: análise hierarquizada de base populacional em uma capital do Brasil-Estudo BRISA. Ciênc Saúde Colet. 2017;22(5):1683-93. doi: https://doi. org/10.1590/1413-81232017225.21722015

12. Klainin P, Arthur DG. Postpartum depression in asian cultures: a literature review. Int J Nurs Stud. 2019;46(10):1355-73. doi: https://doi.org/10.1016/j. ijnurstu.2009.02.012

13. Bronner MB, Knoester H, Last BF, Grotenhuis MA, Bos AP. Follow-up after paediatric intensive care treatment: parental posttraumatic stress. Acta Paediatr. 2018;97(2):181-6. doi: https://doi.org/10.1111/j.1651-2227.2007.00600.x
14. Fonseca GM, Freitas KS, Silva Filho AM, Portela PP, Fontoura EG, Oliveira MAN. Anxiety and depression in family members of people hospitalized in an intensive care unit. Psicol Teor Prat. 2019;21(1):328-43. doi: https://doi.org/10.5935/19806906/psicologia.v21n1p328-343

15. Zivoder I, Martic-Biocina S, Veronek J, Ursulin-Trstenjak N, Sajko M, Paukovic M. Mental disorders/difficulties in the postpartum period. Psychiatr Danub. 2019 [cited 2020 Jun 21];31 Suppl. 3:338-44. Available from: http://www. psychiatria-danubina.com/UserDocslmages/pdf/dnb_vol31_noSuppl\%203/ dnb_vol31_noSuppl\%203_338.pdf

16. Herizchi S, Hosseini MB, Ghoreishizadeh M. The impact of kangaroo-mother care on postpartum depression in mothers of premature infants. Int J Women's Health Reprod Sci. 2017;5(4):312-7. doi: https://doi.org/10.15296/ijwhr.2017.53

17. Fontoura FC, Cardoso MVLML, Rodrigues SE, Almeida PC, Carvalho LB. Anxiety of mothers of newborns with congenital malformations in the pre- and postnatal periods. Rev Latino-Am Enfermagem. 2018;26:e3080. doi: http://doi. org/10.1590/1518-8345.2482.3080

18. Moreira TB, Silva LR, Silva MDB, Silva LJ, Mourão PP, Moreira APA. Maternal experience in the context of breastfeeding of the hospitalized newborn and submitted to surgical intervention. Esc Anna Nery. 2020;24(4):e20190281. doi: https://doi.org/10.1590/2177-9465-ean-2019-0281

19. Kegler JJ, Neves ET, Silva AM, Jantsch LB, Bertoldo CS, Silva JH. Stress in parents of newborns in a neonatal intensive care unit. Esc Anna Nery. 2019;23(1):e20180178. doi: http://doi.org/10.1590/2177-9465-EAN-2018-0178

20. Baseggio DB, Dias MPS, Brusque SR, Donelli TMS, Mendes P.Vivências de mães e bebês prematuros durante a internação neonatal. Temas Psicol. 2017;25(1):153-67. doi: http://doi.org/10.9788/TP2017.1-10 
- Authorship contribution:

Larissa Gouveia de Souza: Conceptualization, data curation, research, writing of the original draft.

Viviane Cordeiro de Queiroz: Formal analysis, visualization and writing of the original draft, revision and editing.

Smalyanna Sgren da Costa Andrade: Conceptualization, data curation, formal analysis, methodology, supervision, visualization and writing of the original draft, revision and editing.

Simone Helena dos Santos Oliveira: Conceptualization, data curation, formal analysis, methodology, supervision, visualization and writing of the original draft, revision and editing.

Edna Samara Ribeiro César: Conceptualization, methodology, formal analysis, visualization and writing of the original draft, revision and editing.

Vilma Felipe Costa de Melo: Conceptualization, methodology, formal analysis, visualization and writing of the original draft, revision and editing.

The authors declare that there is no conflict of interest.

- Corresponding author:

Smalyanna Sgren da Costa Andrade

E-mail: smalyanna@facene.com.br

Associate editor:

Helga Geremias Gouveia

Aproved: 03.26.2021

Editor-in-chief:

Maria da Graça Oliveira Crossetti 